\title{
Using Broadcasting Learning Design to Enhance Student's Experiential Skill
}

https://doi.org/10.3991/ijet.v14i16.10652

\author{
Bayu Kurniawan, Idris ( $\left.{ }^{\varpi}\right)$, Agus Purnomo, Agung Wiradimadja, Sukamto \\ Universitas Negeri Malang, Indonesia \\ idris.fis@um.ac.id
}

\begin{abstract}
This study aims to develop a learning design based on student broadcasting to enhance the student's experiential skill. It provides an alternative learning design for the lecturer of Indonesia history and culture through the use of information technology, especially using video broadcasting in obtaining learning activities and experiences. This research used an ADDIE model—an interactive learning processes model which consists of Analysis, Design, Development, Implementation, and Evaluation. Based on some validations and implementation tests during the learning design process, it was found that the learning design product was considered feasible to be implemented into a learning product and provided some soft skill to the student in news covering, public speaking, editing video, and other experimental skills. It also gave field experiences to enrich the student's creativity in learning process by students broadcasting design on Indonesian history and culture course.
\end{abstract}

Keywords-Indonesian history and culture course, learning design, student broadcasting, and technology.

\section{Introduction}

The high development of education and technology in the last few decades has experienced a significant increase to find formulas for an effective and efficient learning process [1], [2]. The use of information and technology media in the transformative learning design process can help to achieve sustainable development which is one of the goals in the SDGs [3]. The internet of things for technology-based learning paradigm [4] becomes a modern educational orientation and shifts the traditional education paradigm [2] with the basic assumption that it is easily accessible to all [3]. In other words, the development of current learning designs must be able to provide transformative power, participatory learning experiences, and contain an increase in students' soft skills potential [5].

A learning design based on student broadcasting is oriented to outdoor education that can provide a life-based learning experience [6]-[10]. Outdoor education provides many potential experiences that can foster student soft-skills such as teamwork [11], leadership [11]-[14], interest in the learning process [15], creativity and innovation [14], [16], [17], and critical and practical thinking skills [18]. 
Students have had difficulty receiving lecture-based material [19]. This situation makes almost all students in the class become passive and cannot enjoy the learning process. They pretend to listen, open social media on a mobile phone, talk to friends, and often sleep during the learning process. This condition will not provide any experience and meaning to students. They don't get learning experiences that can open their minds and creativity.

Courses that contain complex descriptions [20], require the ability to remember [21], and require interpretive abilities that must be designed to provide knowledge and experience for students [7], [22]. One of these courses is Indonesian History and Culture. This course requires learning design that provides activities in the field for students [23] and they can be directly involved in the learning process through guidance and direction from the lecturers in the learning design [24].

A lecture designed based on student broadcasting can be a solution for students to carry out broadcasting activities that use gadget or information technology by using video editing applications as a learning tool. This activity is considered as a personal activity that they often do in daily activities such as photo editing, video editing, and private broadcasts on their personal social media. The use of personal habits by bringing their world closer to the learning process is expected to explore the potential that exists in the personality of students to become educative and productive activities. By making Indonesian history and culture material as learning material, they conduct outdoor learning by visiting historical sites with the covering news approach as a product of the learning process. The results of the process are then displayed in class and discussed together. These experiences can arouse students' abilities and creativity or become a medium for them to train and improve their skills.

This learning model was developed by combining the process of outdoor class learning with broadcasting activities on television shows such as news programs, talk shows, and documentary videos. The form of the development of this learning model is a syntax that will be applied by lecturers to support the running of the life-based curriculum (BBK) of Universitas Negeri Malang. This model directs students to be divided into small groups which each member has their respective duties such as director, reporter, picture taker (Cameraman), and video editor. They will come into contact with their learning resources directly and carry out broadcasting activities. In addition, students will learn to work together between group members and bring them closer to the lives of professional people in the field of broadcasting.

\section{$2 \quad$ Method}

This research used a research and development method adopted from Borg \& Gall [25]. Research and development is an effort to develop and validate products that will be used in education [25]. This development design would be applied to Indonesian History and Culture material using the ADDIE model which consists of five stagesAnalysis, Design, Development, Implementation, and Evaluation [26]. ADDIE is one of the models in the interactive learning process with the basic stages of learning that are effective, dynamic and efficient [26]. The development design was conducted by 
using product validation through expert validators on the learning models and modules that had been built. There are seven indicators for the design of learning models including Syntax, supporting theory, social system, relation principle, support system, impact, and implementation [27]. In addition, there are four indicators for the learning module including format, language, illustrations, and the contents that are adapted from the model developed by Kurniawan [28] and Sulistyo [29].

\section{Result and Discussion}

\subsection{Initial design development}

The steps in the development stage of the lecture design based on student broadcasting were initiated by forming an initial draft of design development. Furthermore, the initial draft was validated by an expert team which was then revised by the developer based on suggestions and input from the expert team. The results of the development are presented based on expert validation data. The results of this data analysis consist of model expert validation test, validation test of the learning module, and product improvement. Before conducting the validation test for the learning model, the developer designed the initial draft for the design development based on student broadcasting as follow.

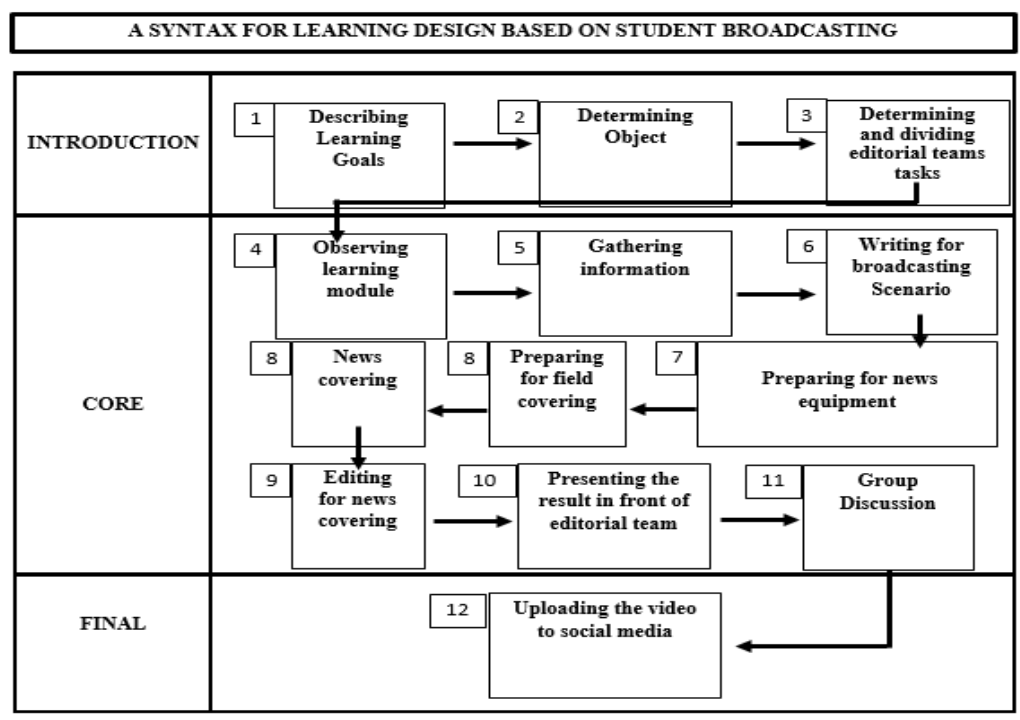

Fig. 1. Syntax for Learning Design

A lecture designed based on the student broadcasting used instruments with syntax consisting of social systems, reaction principles, support systems, and accompaniment effects [27]. It will also be an evaluation that will be conducted by experts in this de- 
velopment. The syntax indicator is an important part of the assessment whether or not the development of this design is appropriate for the results of the assessment.

- The first stage (in Class) was a preliminary activity in the form of apperception, motivation, and delivery of the objectives of the lecture, as well as general explanations regarding lecture material.

- The second stage (in the Class) was the division of the group or editorial team and an explanation of the role of the Team members.

- Furthermore, the third stage (in the Class), the Indonesian History and Culture module was divided and determined by the theme of each Editorial Team and they conducted information and data collection activities based on their respective material themes.

- In the fourth stage (in the Class), they compiled a script based on their respective themes, making preparatory preparations.

- Then, in the fifth stage (in the field / outdoor class), students carried out coverage activities in the field and continued with video editing activities.

- Finally, the sixth stage (in Class), they must present and discuss the results of the coverage, and make conclusions and upload the broadcast video.

This course was designed to be cooperative, project based learning, and outdoor based learning. The lecturer facilitates and motivates students to take place and have democratic attitudes. Students must work in teams for field activities. In addition, lecturers adjusted the assignments given to students based on the material discussed and determined the readiness of students in the learning process. The lecturer gave an assessment of the learning outcomes and provided an assessment based on their competencies and gave an appreciation of the results of their work. Students were given facilities for learning resources such as the Indonesian History and Culture module which is based on student broadcasting as a study guide for students in class and outside the classroom.

The development of student broadcasting design was expected to provide students with compilation of knowledge through reporting processes. In addition, this design provided opportunities for students to develop their skills in broadcasting and develop their soft skills such as teamwork, leadership, caring among team members.

\subsection{Design development validity}

Product designs that had been developed had to be evaluated before being tested. All instruments that had been prepared were validated by experts. This expert test the design whether or not these instruments were used to measure aspects that would be developed and reviewed through measurements that had been made such as items of questions, language usage, and clarity of instructions for using the instrument. The validation was also taken into consideration to perfect the model that would be developed at the trial stage.

The experts, in this development activity evaluated for learning model and learning experts. The learning model would be assessed through the learning steps of the stu- 
dent broadcasting design. While, the learning module would be validated throught the content and clarity of materials. Wahyu Djoko Sulistyo, M.Pd was a learning model evaluator. He is a lecturer from the history department of the Faculty of Social Sciences, Universitas Negeri Malang. The learning module expert will evaluate the content of the material presented in the learning module that has been prepared by the designer team. The module experts who were appointed to validate the learning module were Neni Wahyuningtyas, M.Pd as a lecturer at the Social Studies Program of Universitas Negeri Malang.

The results of the validation test for the learning model are shown in the table as follows:

Table 1. The Result of Learning Model Validity

\begin{tabular}{|c|c|c|c|c|c|c|c|c|}
\hline Aspect & $\begin{array}{c}\text { Supporting } \\
\text { Theory }\end{array}$ & Syntax & $\begin{array}{c}\text { Social } \\
\text { System }\end{array}$ & $\begin{array}{c}\text { Relation } \\
\text { principle }\end{array}$ & $\begin{array}{c}\text { Supporting } \\
\text { System }\end{array}$ & Impact & Implem. & Average \\
\hline $\begin{array}{c}\text { Learning } \\
\text { Model (\%) }\end{array}$ & 80 & 95 & 80 & 100 & 87 & 87 & 100 & 90 \\
\hline
\end{tabular}

Data analysis provided by a learning expert was aimed at knowing the feasibility of the model that would be applied in the learning process. Based on the assessment of the supporting theory aspects of the evaluation, syntax, social system, the principle of relations, support systems, accompaniment effects, and implementation, the average results obtained are $90 \%$. The lowest value is the supporting theory and the social system (80). The highest value is the principle of relations and implementation (100). This shows that the learning model developed has a good and feasible category. The percentage from the results of the learning expert validation, related to the design of Student Broadcasting, is declared feasible to be applied in the learning process with the revisions and suggestions given by model experts. Suggestions for revisions given including simplifying learning steps and clarifying the necessary parts.

Based on the results of the assessment, the conclusion is that the learning model can be used by revising the parts specified by the expert. In general, the assessment criteria can be seen in the percentage tables and diagrams that students will use in a lecture design based on student broadcasting approach.

The results of the validation test related to the learning module are shown in the table as follows.

Table 2. The Result of Learning Module Validity

\begin{tabular}{|c|c|c|c|c|c|}
\hline Aspect & Format & Language & Illustration & Content & Average \\
\hline Learning Module (\%) & 80 & 68 & 85 & 87 & 80 \\
\hline
\end{tabular}

Table 2 indicates the data analysis provided by experts in determining the feasibility of the module that will be used to help students in the learning process. The aspects of assessment include format, language, illustration, and content. Based on the results of the analysis, the average value is $80 \%$. The lowest value is in the language aspect (68), while the highest value is content (87) and the illustration aspect is 85 . This shows that the learning module developed has a good category. 
The percentage of the learning expert validation, related to the lectures design based on student broadcasting, is declared appropriate for use in the learning process with the revisions and suggestions given by the expert. Suggestions for revisions given are improvements to the use of language that is simple and easy to understand by students.

\subsection{Completion stages}

Based on the results of model validation and learning modules that have been assessed by experts, there were several inputs provided who help designer to revise the learning design. The revised syntax results are as follows.

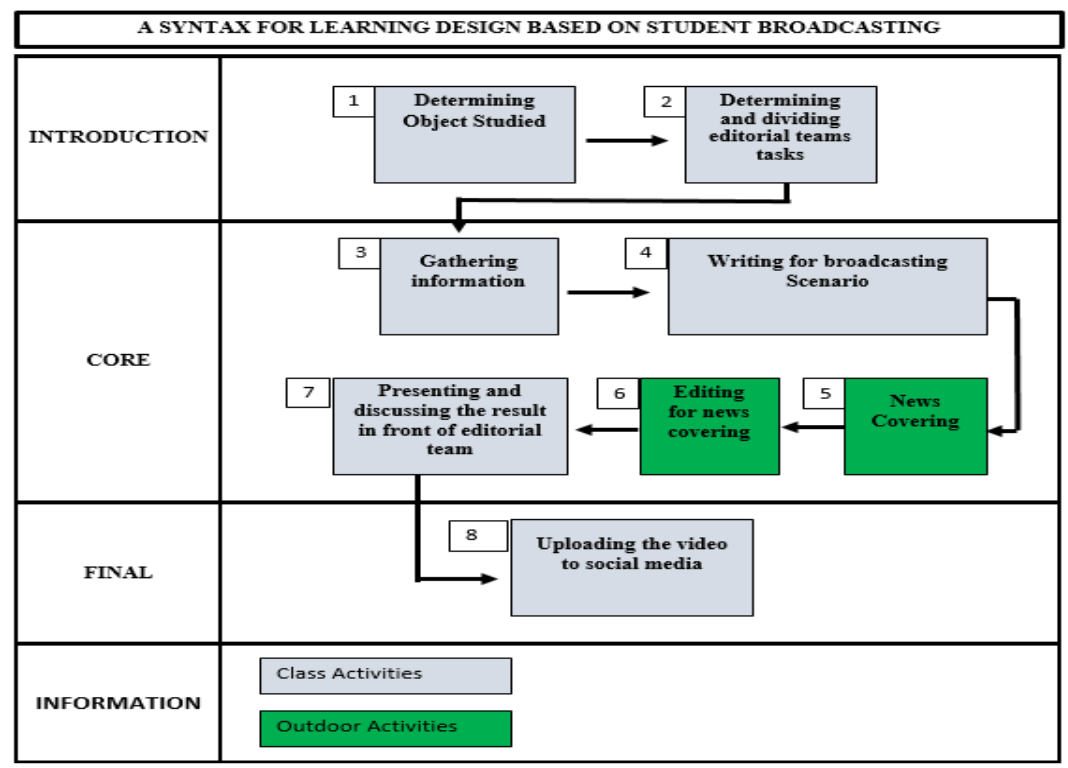

Fig. 2. Syntax Completion for Learning Design

Figure 2 shows the simplification of steps in learning design, for example, in the introduction after the revision process is simplified to only two steps. Another simplification that gets a lot of input from experts is in the core part of the design which is simplified from nine steps to five steps with the distribution of activities outside the classroom and in the classroom.

The development of student broadcasting learning design was implemented based on Semester Course Planning (RPS). The stages were implemented according to the number of meetings in one semester. The stages were divided into stages of activities in the classroom and in the field (outdoor class). The former consisted of pre-field and post-field student learning activities. The later contained coverage activities.

The pre-field stage was held for eight meetings. The meeting in the pre-field stage was divided into two sessions: 
- A conceptual understanding and a presentation session

- A scenario and a presentation session

The first session was held in four meetings and the second session was held in four meetings. The first session, student learning activities consisting of theoretical studies related to the understanding of the concepts of history and culture, theoretical studies related to cultural results in the pre-history, Hindu-Buddhist, and Islam. In addition, the editorial team also collected information and data. They had to present the data and information they had found in the field. All learning activities in this first session were held in meetings 1-4. The second session, student learning activities consisted of activities arranging script scenarios in the field. After the screenplay script had been completed, the editorial team would present the results to other editorial teams. In addition, the editorial team also presented the equipment needed in the field. All learning activities in this session were held at 5-7 meetings. The 8th meeting was an evaluation activity in the form of a midterm exam.

The stage in the field was a continuation of pre-field activities. At this stage, student learning activities were divided into two sessions. The first session was covering activities and the second session was editing activities. The entire learning activity at this stage was carried out at the 9-12 meeting.

The first session was coverage activities. Students go to the coverage location according to the planning in the pre-field activities. Supporting equipment and scenario scripts that had been prepared were implemented at this stage. The second session was editing activities. During this session the editorial staff and editors played an important role in producing good coverage videos.

The post-field stages were carried out at the 13-15 meeting, while the 16th meeting was an evaluation, final semester examination (UAS). The activity at this stage was the presentation of the results of the coverage of each editorial team. Each editorial team then gave a discussion and question and answer session with the other editorial team, as well as uploading video broadcasting on YouTube. Activities at the 16th meeting were the final semester exam.

\section{Conclusion}

Design development in student broadcasting-based learning can not only provide opportunities for students to interact directly with nature and society [11], [22], but can also explore individual potential and hone it into skills [7] that they can use for real life in their environment. The combination of outdoor and indoor learning (knowledge and experiences) provides a practical and theoretical learning experience where students not only learn to memorize Indonesian history and culture, but also understand in a participatory manner the substance behind these historical and cultural meanings. 


\section{$5 \quad$ References}

[1] I. U. Khan, Z. Hameed, Y. Yu, T. Islam, Z. Sheikh, and S. U. Khan, "Predicting the acceptance of MOOCs in a developing country: Application of task-technology fit model, social motivation, and self-determination theory," Telemat. Inform., vol. 35, no. 4, pp. 964-978, Jul. 2018. https://doi.org/10.1016/j.tele.2017.09.009

[2] K. H. Lau, T. Lam, B. H. Kam, M. Nkhoma, J. Richardson, and S. Thomas, "The role of textbook learning resources in e-learning: A taxonomic study," Comput. Educ., vol. 118, pp. 10-24, Mar. 2018. https://doi.org/10.1016/j.compedu.2017.11.005

[3] D. Gibson, T. Broadley, J. Downie, and P. Wallet, "Evolving Learning Paradigms," p. 13, 2019.

[4] K.-S. Hong, A. A. Ridzuan, and M.-K. Kuek, "Students' attitudes toward the use of the Internet for learning: A study at a university in Malaysia," p. 6, 2019.

[5] Y. Jung and J. Lee, "Learning Engagement and Persistence in Massive Open Online Courses (MOOCS)," Comput. Educ., vol. 122, pp. 9-22, Jul. 2018. https://doi.org/10. 1016/j.compedu.2018.02.013

[6] J. Bennion and B. Olsen, "Wilderness writing: Using personal narrative to enhance outdoor experience," J. Exp. Educ., vol. 25, no. 1, pp. 239-246, 2002. https://doi.org/10. $1177 / 105382590202500108$

[7] D. S. Berman and J. Davis-Berman, "Positive psychology and outdoor education," J. Exp. Educ., vol. 28, no. 1, pp. 17-24, 2005.

[8] A. Brantley, "Learning Outside the Classroom," Phil Delta Kappan, vol. 98, no. 8, pp. 70$75,2014$.

[9] J. James and T. Williams, "School-Based Experiental Outdoor Education: A Neglected Necessity," J. Exp. Educ., vol. 40, no. 1, pp. 58-71, 2017.

[10] S. Schumann and J. Sibthorp, "Improving the Accuracy of Outdoor Educators' Teaching Self-Efficacy Beliefs Through Metacognitive Monitoring," J. Exp. Educ., vol. 39, no. 2, pp. 196-210, 2016. https://doi.org/10.1177/1053825916640540

[11] K. Laeeq and Z. A. Memon, "An Integrated Model to Enhance Virtual Learning Environments with Current Social Networking Perspective," Int. J. Emerg. Technol. Learn. IJET, vol. 13, no. 09, p. 252, Sep. 2018. https://doi.org/10.3991/ijet.v13i09.8000

[12] S. C. Field, L. L. Lauzon, and J. T. Meldrum, "A phenomenology of outdoor education leader experiences," J. Exp. Educ., vol. 39, no. 1, pp. 31-44, 2016.

[13] A. Hayashi and A. Ewert, "Outdoor leaders' emotional intelligence and transformational leadership,” J. Exp. Educ., vol. 28, no. 3, pp. 222-242, 2006.

[14] C. P. Purwadita, A. Sudiro, M. Mugiono, and I. Idris, "Innovation in leadership and team performance: Evidence from indonesia property agent industry," Manag. Econ. J. MEC-J, vol. 2, no. 2, pp. 133-151, 2018. https://doi.org/10.18860/mec-j.v0i1.5221

[15] K. R. Adi, I. Idris, and F. Rosyida, "Game quiz dalam kegiatan lesson study sebagai penggugah minat belajar mahasiswa," Proceeding Nas. PIPS, pp. 72-78, 2018.

[16] S. Chootongchai and N. Songkram, "Design and Development of SECI and Moodle Online Learning Systems to Enhance Thinking and Innovation Skills for Higher Education Learners," Int. J. Emerg. Technol. Learn. IJET, vol. 13, no. 03, p. 154, Mar. 2018. https://doi.org/10.3991/ijet.v13i03.7991

[17] A. Sani, V. Ekowati, I. S. Wekke, and I. Idris, "Respective contribution of entrepreneurial leadership through organizational citizenship behavior In creating employees performance," Acad. Entrep. J., vol. 24, no. 4, pp. 1-11, 2018.

[18] I. R. Williams, L. M. Rose, C. A. Olsson, G. C. Patton, and N. B. Allen, "The Impact of Outdoor Youth Programs on Positive Adolescent Development: Study Protocol for a Controlled Crossover Trial," Int. J. Educ. Res., vol. 87, pp. 22-35, 2018. https://doi.org/10. 1016/j.ijer.2017.10.004

[19] S. Mutmainah, "Pengaruh penerapan metode pembelajaran kooperatif Berbasis kasus yang berpusat pada mahasiswa terhadap Efektivitas pembelajaran akuntansi keperilakuan," 2008. https://doi.org/10.18202/jamal.2011.12.7134

[20] F. Luwistiana and S. Sumiyatun, "Pemahaman mahasiswa sejarah terhadap materi perkuliahan pendidikan," Khazanah Pendidik., vol. 3, no. 2, 2011. 
[21] B. A. Pribadi, Desain dan Pengembangan Program Pelatihan Berbasis Kompetensi Implementasi Model ADDIE. Jakarta: Kencana, 2016.

[22] N. Nonthamand and J. Na-Songkhla, "The Correlation of Open Learning, Collaboration, Learning Tools, and Creative Problem Solving by Graduate Students in Thailand," Int. J. Emerg. Technol. Learn. IJET, vol. 13, no. 09, p. 280, Sep. 2018. https://doi.org/10.3991/ ijet.v13i09.7835

[23] J. Susanto, "Pengembangan perangkat pembelajaran berbasis lesson study dengan kooperatif tipe numbered heads together untuk meningkatkan aktivitas dan hasil belajar IPA di SD," J. Prim. Educ., vol. 1, no. 2, 2012. https://doi.org/10.26418/jpmipa.v6i2. 17335

[24] Sardiman, Interaksi dan Motivasi Belajar Mengajar. Jakarta: Raja Grafindo Persada, 2010.

[25] R. W. Borg and M. D. Gall, Educational Research; An Introduction, 5th ed. UK: Longman Inc., 1989.

[26] R. M. Branch, and T. J. Kopcha, Instructional design models: Handbook of research on educational communications and technology. New York: Springer, 2014.

[27] B. Joyce, M. Weil, and E. Calhoun, "Models of teaching," Cent. Teach. Technol. - Book Libr., p. 96, 2003.

[28] B. Kurniawan, "Model pembelajaran IPS berbasis nilai simbolisme kain Songket untuk meningkatkan solidaritas sosial siswa di SMP Negeri 6 Kayuagung," PhD Thesis, Universitas Sebelas Maret, 2016. https://doi.org/10.25273/gulawentah.v1i1.28

[29] W. D. Sulistyo, "Pengembangan model pembelajaran sejarah berbasis nilai-nilai serat wicara keras untuk meningkatkan kemampuan berfikir kritis siswa SMA Insan Cendekia Al Mujtaba Sukoharjo," PhD Thesis, Universitas Sebelas Maret, 2016. https://doi.org/10. $\underline{32616 / \text { tdb.v7 } 1 \cdot 36.61-70}$

\section{Authors}

Bayu Kurniawan is an Indonesian Historical Education, one of the lecturers in Faculty of Social Science, Universitas Negeri Malang. His research interest is education and learning innovation.

Idris is one of the lecturers in Social Studies Program, Faculty of Social Science, Universitas Negeri Malang. He is interested in learning innovation.

Agus Purnomo is a lecturer in Faculty of Social Science, Universitas Negeri Malang, Indonesia. She is majoring in Geography and mastering in learning media and related information technology in education.

Agung Wiradimadja is a social studies lecturer in Faculty of Social Science, Universitas Negeri Malang, Indonesia. He is majoring in social studies.

Sukamto is a senior lecturer in Faculty of Social Science, Universitas Negeri Malang. His study concerns in social construction theory and social phenomena.

Article submitted 2019-04-12. Resubmitted 2019-06-08. Final acceptance 2019-06-13. Final version published as submitted by the authors. 